\title{
Abundance and grazing effects of Cyclosalpa bakeri in the subarctic Pacific
}

\author{
L. P. Madin ${ }^{1, *}$, J. E. Purcell ${ }^{2}$, C. B. Miller ${ }^{3}$ \\ ${ }^{1}$ Woods Hole Oceanographic Institution, Woods Hole, Massachusetts 02543, USA \\ ${ }^{2}$ University of Maryland Center for Environmental Science, Horn Point Laboratory, PO Box 775, Cambridge, Maryland 21613, USA \\ ${ }^{3}$ College of Oceanic and Atmospheric Sciences, Oregon State University, Corvallis, Oregon 97331, USA
}

\begin{abstract}
Ecological effects of populations of the salp Cyclosalpa bakeri were studied in late summer of 1984, 1987 and 1988 during the Subarctic Pacific Ecosystem Research (SUPER) project at Station P in the northeast Pacific. Salps occurred largely in the top $60 \mathrm{~m}$, with biomass values ranging from 76 to $3621 \mathrm{mg} \mathrm{C} \mathrm{m}^{-2}$. Three approaches were taken to estimate the grazing impact of these populations. C. bakeri removed from 1.6 to $136.6 \%$ of daily primary production and 1.3 to $56.8 \%$ of the diatom stocks in August 1988. On average, feeding rates of the salps predicted clearance of all particles $\geq 5.0 \mu \mathrm{m}$ from 1.2 to $49.2 \%$ of the water column per day in 1984 and 1988 . Although excretion of dissolved $\mathrm{N}$ appears negligible, production of fecal $\mathrm{C}$ and $\mathrm{N}$ can be high, as much as $875 \mathrm{mg} \mathrm{C}$ and $110 \mathrm{mg}$ $\mathrm{N} \mathrm{m}^{-2} \mathrm{~d}^{-1}$ at the highest population density sampled. Although the salps probably do not have a significant grazing impact on the small cells $(\leq 5.0 \mu \mathrm{m})$ which are responsible for most of the production, they may be important in controlling populations of diatoms which typically occur in late summer at Station P.
\end{abstract}

KEY WORDS: Salps $\cdot$ Grazing $\cdot$ Subarctic Pacific $\cdot$ Station P $\cdot$ Diatoms

\section{INTRODUCTION}

The subarctic Pacific region has long been of ecological interest because of its persistent high nutrient concentrations and lack of a seasonal phytoplankton bloom, both sharp contrasts to comparable latitudes in the Atlantic. During the 1980s the Subarctic Pacific Ecosystem Research (SUPER) program conducted a series of cruises to Ocean Station $\mathrm{P}\left(50^{\circ} \mathrm{N}, 145^{\circ} \mathrm{W}\right)$ to study the relationships between production and grazing in this region. The main results of this program have been reported in a series of papers in the last 5 years (cited in Miller 1993).

The first hypothesis ('major grazer' hypothesis) advanced to explain the observed nutrient levels and phytoplankton stocks was that the life history of the dominant herbivorous copepods in the north Pacific, species of Neocalanus and Eucalanus, allowed them to begin feeding early in the year, before the seasonal

\footnotetext{
•E-mail:Imadin@whoi.edu
}

acceleration of phytoplankton growth, and this timing prevented the accumulation of bloom densities of phytoplankton (Beklemishev 1957, Heinrich 1962). Although the phytoplankton community is dominated by very small cells (Booth et al. 1982, Booth 1988), it was hypothesized that Neocalanus spp. were able to graze them by virtue of the closely spaced setae on their filtering appendages. However, experimental determination of the feeding rates of the larger crustacean grazers (Dagg \& Walser 1987, Dagg 1993a) showed that the grazing capacity present was in fact much too low to keep up with the measured growth of phytoplankton. Indeed, ingestion of phytoplankton alone was often insufficient to meet the metabolic needs of the copepods (Dagg \& Walser 1987, Dagg 1993b), and it was inferred that ingestion of microzooplankton made up the remainder of their diet.

Other work at Station P has shown that phytoplankton populations appear to be kept in check by microzooplankton rather than macrozooplankton grazing. The rapid regeneration of nitrogen as $\mathrm{NH}_{4}{ }^{+}$by the protozoans fuels the continued primary production, 
and what $\mathrm{NO}_{3}{ }^{-}$is depleted during the summer and fall is replaced by winter mixing. Estimates of the relative importance of microzooplankton and macrozooplankton grazing based on the chlorophyll-budget method showed that the protozoans accounted for between 70 and $93 \%$ of total grazing on 4 cruises in 1987 and 1988 (Miller et al. 1991). This role of protozoan grazing, together with the effects of mixing and the possibility of iron limitation for the growth of large cells, are the principal elements of the 'new SUPER synthesis' hypothesis (Miller et al. 1991, Miller 1993).

The 'major grazers' that were initially of interest in this system were copepods in the genera Neocalanus and Eucalanus. Other herbivorous zooplankton present at Station $P$ at various times during the year include euphausiids and salps, notably Cyclosalpa bakeri. Salps are highly effective filter feeders (Alldredge \& Madin 1982, Madin \& Deibel 1997) with clearance rates up to several liters $\mathrm{h}^{-1}$ individual ${ }^{-1}$, and the capability of removing particles down to a few $\mu \mathrm{m}$ in size. Salps sometimes occur in dense populations (Wiebe et al. 1979, Le Borgne 1983) which arise rapidly as a result of high rates of growth and asexual reproduction under favorable conditions (Heron 1972, Andersen \& Nival 1986, Madin \& Deibel 1997).

The presence of large numbers of Cyclosalpa bakeri at Station P in August of 1984 led the SUPER participants to wonder about the importance of their grazing on phytoplankton stocks in summer. Two of us (L.P.M, J.E.P.) joined cruises in September 1987 (SUPER IV) and August 1988 (SUPER VI) to investigate the life history, energetics and grazing effects of this species. Earlier papers have described diel patterns of migration, feeding and reproduction in C. bakeri (Purcell \& Madin 1991), and their feeding, metabolism and growth (Madin \& Purcell 1992). Here we present data concerning their abundance and impacts as grazers and recyclers of carbon and nitrogen.

\section{METHODS}

Sampling. Saips were observed and collected at Ocean Station P $\left(50^{\circ} \mathrm{N}, 145^{\circ} \mathrm{W}\right)$ on 3 SUPER program cruises. In August 1984 (SUPER II), 2 day and 2 night tows were made in the top $100 \mathrm{~m}$ with a closing Puget Sound net. In September-October 1987 (SUPER IV), a $1 \mathrm{~m}^{2}$ MOCNESS (333 $\mu \mathrm{m}$ mesh) was used for vertically stratified zooplankton sampling, but no salps were caught with it. In August 1988 (SUPER VI), the $1 \mathrm{~m}^{2}$ MOCNESS was deployed for 3 sets of day/night tows from approximately $60 \mathrm{~m}$ to the surface, which did catch salps. Day and night SCUBA diving collections of Cyclosalpa bakeri were made both in 1987 (10 dives) and 1988 (13 dives) by 2 tethered divers during dives lasting approximately $20 \mathrm{~min}$. In addition to collecting, 1 diver (L.P.M.) estimated abundance based on nearest neighbor distances or visual assessment of apparent density

All net-collected salps were preserved in 5\% formalin for later counting and measurement. To determine the extent of shrinkage due to preservation, samples of salps were measured live (body length from oral to atrial siphon) and then fixed in $5 \%$ formalin, and measured again after 5 mo. Sizes of salps collected in the MOCNESS tows were corrected for shrinkage, which averaged $11.6 \%$. Specimens collected by divers in 1987 and 1988 were measured alive before being used for shipboard experiments. Conversion from body length to carbon weight was made using a regression equation based on subsamples of the diver-collected salps $\left[\mathrm{C}(\mathrm{mg})=0.0051 \times\right.$ length $(\mathrm{mm})^{1.75}, \mathrm{r}^{2}=0.83, \mathrm{n}=$ 47; Madin \& Purcell 19921

Feeding and metabolic rates. Estimates of grazing effects of the salp populations are based on rates of feeding, defecation and nitrogen excretion determined using diver-collected Cyclosalpa bakeri. Methods and results of this work are described in detail by Madin $\&$ Purcell (1992), and are only summarized here. Feeding rates were calculated from quantities of plant pigments in the feces of freshly collected salps and from gut passage times measured on shipboard. Loss of pigments due to digestive degradation was estimated by using diatom frustules in salps guts as conservative tracers of ingestion. Comparison of clearance rates based on pigment versus diatom frustules indicated a pigment loss of about $50 \%$; accordingly, clearance rates for $C$. bakeri were corrected by a factor of 2.2 on a length basis or 2.5 on a weight basis. The salps were also found to feed mainly at depth during daylight hours, despite diel migration into surface waters at night (Purcell \& Madin 1991). The clearance rate used in this paper for estimation of population grazing effects is the mean weight-specific value for 162 salps collected during daylight on dives made in 1987 and 1988.

Respiration and excretion were measured in shortterm ( 3 to 11 h duration, 1 l container) batch experiments on shipboard, and defecation rate was observed in salps maintained in continuous flow aquaria with ambient particle concentrations.

\section{RESULTS}

\section{Physical and biological environment}

Physical conditions were fairly similar from year to year, and quite uniform within the depth ranges where the Cyclosalpa bakeri occurred. In general, water tem- 
perature in the top $60 \mathrm{~m}$ was between 11 and $13^{\circ} \mathrm{C}$ in August-September. Profiles of temperature, salinity and chlorophyll (chl) concentrations relative to distribution of the salps in 1988 are given by Purcell \& Madin (1991). Distribution of nutrients is described by Wheeler (1993) and chlorophyll stock and primary production data are detailed in Welschmeyer et al. (1993).

\section{Abundance and vertical distribution of Cyclosalpa bakeri}

Populations of Cyclosalpa bakeri were present at Station $P$ on all 3 summer cruises in the SUPER program, but were sampled quantitatively only in August 1984 (SUPER II) and August 1988 (SUPER VI). In August 1987 (SUPER IV), C. bakeri were collected by divers for experimental work on feeding and energetics, but none were caught in the $1 \mathrm{~m}^{2}$ MOCNESS nets towed at the same times and places. The diver's estimates of density from 1987 suggest that at values much below $1 \mathrm{~m}^{-3}$ salps were too sparse to be collected with nets (Table 1). Diver estimates for density in 1988 were 4 times greater than the maximum MOCNESS values (see below), probably because divers tended to work in strata of high concentration. Although diver estimates show that salps were much more abundant in 1988 , divers were able to collect comparable numbers of salps in both years (Table 1). This demonstrates the advantage of visually directed in situ collecting for sparse organisms.

Net tows made in 1984 and 1988 did collect significant numbers of Cyclosalpa bakeri. Abundance and carbon biomass of these salps, integrated over the sampled water column, is given in Table 2 , and the depth distributions of the salps are shown in Fig. 1. The salps were restricted to the upper $100 \mathrm{~m}$ or less of the water column, and undertook a diel vertical migration within this depth range (Purcell \& Madin 1991). Mean salp densities at these stations ranged from about 1 to 31 salps $\mathrm{m}^{-3}$. Numbers and biomass sampled by day
Table 2. Cyclosalpa baker. Abundance and bıomass at Station P in August 1984 and 1988. Values are integrated numbers and carbon biomass in the indicated depth range, based on stratified tows with a Puget Sound net (1984) or $1 \mathrm{~m}^{2}$ MOCNESS (1988). Times are local

\begin{tabular}{|c|c|c|c|c|}
\hline Sample date & Depth range (m) & Time & Salps $\mathrm{m}^{-2}$ & $\mathrm{mgC} \mathrm{m} \mathrm{m}^{-2}$ \\
\hline 3 Aug 1984 & $0-40$ & $22: 10$ & 508 & 262.5 \\
\hline 5 Aug 1984 & $40-100$ & $10: 25$ & 780 & 560.4 \\
\hline 7 Aug 1984 & $40-100$ & $11: 10$ & 480 & 447.0 \\
\hline 9 Aug 1984 & $0-50$ & $21: 58$ & 290 & 293.6 \\
\hline 10 Aug 1988 & $0-63$ & $22: 45$ & 240 & 344.2 \\
\hline 11 Aug 1988 & $0-57$ & $11: 00$ & 208 & 335.5 \\
\hline 13 Aug 1988 & $0-62$ & $22: 30$ & 57 & 94.6 \\
\hline 14 Aug 1988 & $0-60$ & $09: 40$ & 55 & 76.1 \\
\hline 24. Aug 1988 & $0-58$ & $21: 50$ & 1842 & 3621.5 \\
\hline 26 Aug 1988 & $0-60$ & $09: 30$ & 314 & 492.6 \\
\hline
\end{tabular}

and night match within a factor of 2 for most day/night pairs, but there is a great disparity for the third sample date in 1988 (Table 2). Rough seas and an extra day between the day and night tows may have brought about this change in the population density of the salps through drift or advection.

\section{Effects of feeding and metabolism}

We used 3 approaches to estimate the fraction of the phytoplankton stock or production removed by Cyclosalpla bakeri at Station P. Originally egestion rate of pigment was measured and converted to an ingestion rate by correcting for pigment destruction due to digestion (Madin \& Purcell 1992). Pigment ingestion can be compared directly to pigment standing stocks, or used to estimate carbon ingestion via an appropriate C:chl ratio. Because the salps stop feeding at night, we have based impact estimates on $16 \mathrm{~h} \mathrm{~d}^{-1}$ of feeding activity. This is the most direct approach when values for phytoplankton stocks, production and salp ingestion are all known for the same dates. In Table 3 , weight-specific rates of chlorophyll ingestion by $C$.

Table 1. Summary of dive collections at Station P. Dives were made between 20 September and 3 October 1987 and between 4 and 21 August 1988. D/N: day or night dives; maximum depth: maximum reached by divers (mean \pm SD). Numbers of salps collected per dive are shown as mean \pm SD for the number of dives in each row. Collection rate is total number collected divided by total dive duration. Visual estimates of number of aggregate whorls $\mathrm{m}^{-3}$ were multiplied by the mean number of salps whorl ${ }^{-1}$

(12) to estimate number of individual salps $\mathrm{m}^{-3}$. The number of density estimates is in parentheses

\begin{tabular}{|c|c|c|c|c|c|c|}
\hline Year & $\mathrm{D} / \mathrm{N}$ & No. of dives & $\begin{array}{l}\text { Mean maximum } \\
\text { depth }(\mathrm{m})\end{array}$ & $\begin{array}{l}\text { Mean no. salps } \\
\text { collected }\end{array}$ & $\begin{array}{l}\text { Collection rate } \\
\text { (salps } \mathrm{min}^{-1} \text { ) }\end{array}$ & $\begin{array}{l}\text { Estimated density } \\
\quad\left(\text { salps } \mathrm{m}^{-3}\right) \text { (n) }\end{array}$ \\
\hline 1987 & $\begin{array}{l}\mathrm{D} \\
\mathrm{N}\end{array}$ & $\begin{array}{l}6 \\
4\end{array}$ & $\begin{array}{l}24.8 \pm 5.4 \\
16.5 \pm 1.7\end{array}$ & $\begin{array}{r}81 \pm 47 \\
106 \pm 37\end{array}$ & $\begin{array}{l}4.2 \\
4.1\end{array}$ & $\begin{array}{c}0.7 \pm 0.3(4) \\
-\end{array}$ \\
\hline 1988 & $\begin{array}{l}\mathrm{D} \\
\mathrm{N}\end{array}$ & $\begin{array}{l}7 \\
6\end{array}$ & $\begin{array}{l}31.7 \pm 2.9 \\
20.8 \pm 1.9\end{array}$ & $\begin{array}{l}94 \pm 40 \\
81 \pm 28\end{array}$ & $\begin{array}{l}6.5 \\
3.7\end{array}$ & $\begin{array}{c}124 \pm 77(4) \\
-\end{array}$ \\
\hline
\end{tabular}


a

3, 5, 7 \& 9 August 1984

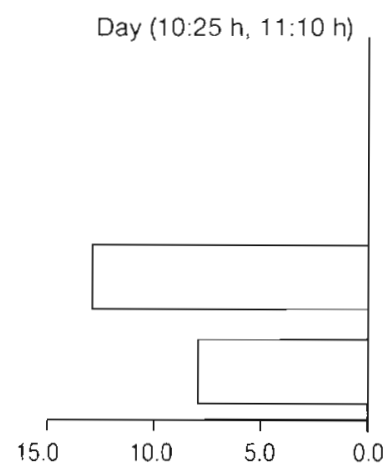

b

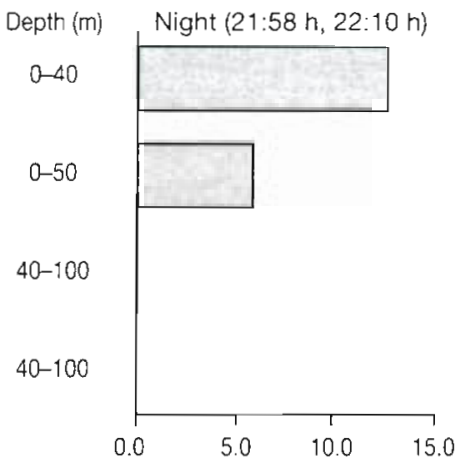

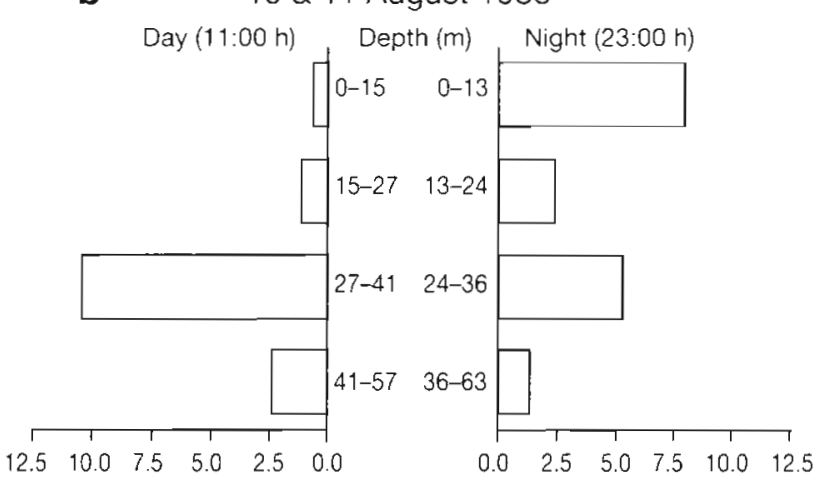

C

13 \& 14 August 1988

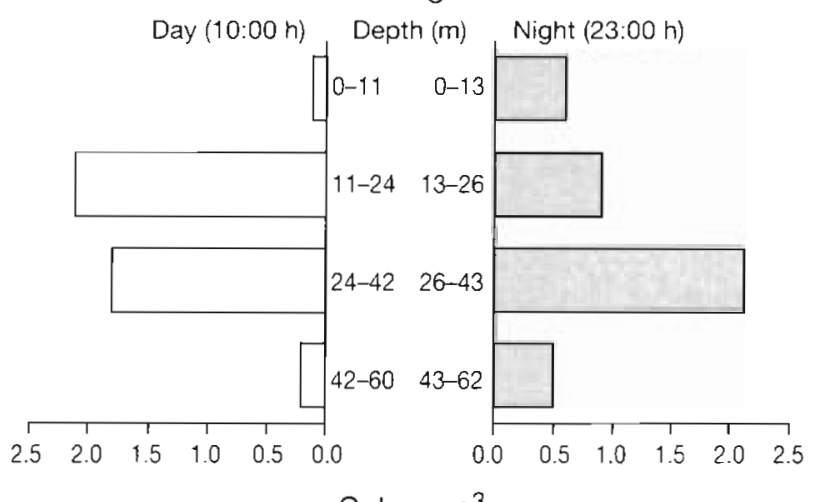

Salps $\mathrm{m}^{-3}$

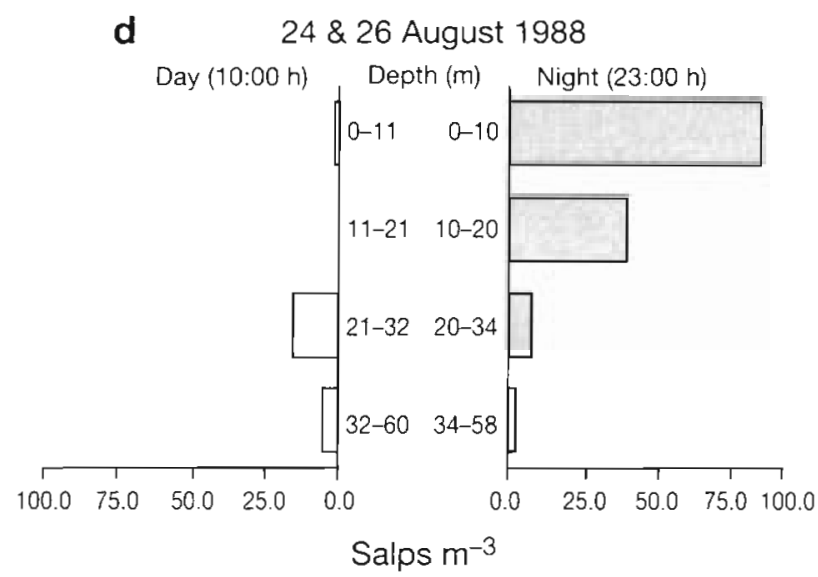

Fig. 1. Cyclosalpa bakeri. Vertical distribution, as numbers of salps $\mathrm{m}^{-3}$, at Station P. (a) 3-5 and 7-9 August 1984, Puget Sound

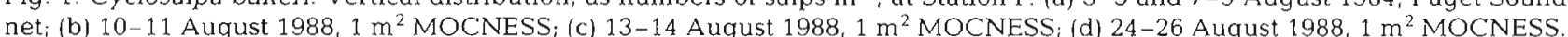
Note that abundance scales are different for each plot, and that depth ranges sampled vary slightly on different sampling dates. Times are local

bakeri, based on data from salps collected in August 1988, are multiplied by the salp stock (Table 2) to calculate total ingestion by the population.

Values for chl standing stock and primary production for the same dates are taken from Welschmeyer et al. (1993), integrated over the $60 \mathrm{~m}$ depth in which salps were sampled. Chl in cells $\geq 5.0 \mu \mathrm{m}$ was estimated from the proportion of carbon biomass (46\%) represented by autotrophic cells $\geq 5.0 \mu \mathrm{m}$ in August 1988 (data from Booth et al. 1993). Primary production in $\mathrm{mg} \mathrm{C}$ was converted to $\mathrm{mg}$ chl using $\mathrm{C}$ :chl ratios based on cell counts made on the 3 dates in the table (Booth et al. 1993). These comparisons indicate that salp populations can ingest anywhere from a few percent to over

Table 3. Cyclosalpa baken. Chlorophyll ingestion on 3 dates in August 1988 relative to chlorophyll stock and production. Pigment ingestion rate (as chl a equivalents): mean \pm SD for salps collected by divers on those dates; $N$ : number of data points. Salp biomass: mean of values from adjacent day and night MOCNESS collections, except for August 24-26, which is night value only. Stock and primary production data from Welschmeyer et al. (1993), converted to $\mathrm{mg}$ chl a from mg C using C:chl ratios determined from cell counts on the same dates (Booth et al. 1993). Size fractionation of chlorophyll estimated from data on cell size distribution (Booth et al. 1993). All values are integrated over the $60 \mathrm{~m}$ depth in which salps were collected

\begin{tabular}{|c|c|c|c|c|c|c|c|c|c|c|}
\hline Date & $\begin{array}{l}\text { Ingestion } \\
(\mathrm{mg} c h l a \\
\left.\mathrm{mg}^{-1} \mathrm{Ch}^{-1}\right)\end{array}$ & $N$ & $\begin{array}{c}\text { Salp } \\
\text { biomass } \\
\left(\mathrm{mg} \mathrm{C} \mathrm{m}^{-2}\right)\end{array}$ & $\begin{array}{c}\text { Chl a } \\
\text { ingestion } \\
\left(\mathrm{mg} \mathrm{m}^{-2} \mathrm{~d}^{-1}\right)\end{array}$ & $\begin{array}{c}\text { Chl a } \\
\text { stock } \\
\left(\mathrm{mg} \mathrm{m}^{-2}\right)\end{array}$ & $\begin{array}{l}\text { Percent } \\
\text { ingested } \\
\text { by salps }\end{array}$ & $\begin{array}{c}\text { Chl } a \text { in cells } \\
\geq 5 \mu \mathrm{m} \\
\left(\mathrm{mg} \mathrm{m}^{-2}\right)\end{array}$ & $\begin{array}{c}\text { Percent } \\
\text { ingested } \\
\text { by salps }\end{array}$ & $\begin{array}{c}\text { Primary } \\
\text { production } \\
\left(\mathrm{mg} \mathrm{m} \mathrm{m}^{-2} \mathrm{~d}^{-1}\right)\end{array}$ & $\begin{array}{l}\text { Percent } \\
\text { ingested } \\
\text { by salps }\end{array}$ \\
\hline $10-1.1$ & $0.086 \pm 0.030$ & 35 & 344 & 1.18 & 25.2 & 4.7 & 12.9 & 9.1 & 9.2 & 12.8 \\
\hline $13-14$ & $0.052 \pm 0.028$ & 24 & 85 & 0.18 & 18.2 & 1.0 & 9.3 & 1.9 & 11.4 & 1.6 \\
\hline $24-26$ & $0.050 \pm 0.025$ & 28 & 3621 & 7.24 & 16.0 & 45.3 & 8.2 & 88.3 & 5.3 & 136.6 \\
\hline
\end{tabular}


Table 5. Cyclosalpa bakeri. Effects of salp populations at Station P in August 1984 and 1988. Salp biomass is mean of values from adjacent day and night collections, except for $24-26$ August 1988 which is night value only. All effects are integrated over the indicated depth during $16 \mathrm{~h}$ of daylight, except nitrogen excretion, wich is over $2.4 \mathrm{~h}$ (Purcell \& Madin 1991). Percent of water cleared is the fraction of the water column fittered per day; all particles $\geq 5.0 \mu \mathrm{m}$ would be removed from this fraction. Nitrogen excretion (principally $\mathrm{NH}_{4}{ }^{+}$) is the mean concentration resulting from salp excretion, assuming uniform distribution throughout the indicated water column

\begin{tabular}{|c|c|c|c|c|c|c|}
\hline Date & $\begin{array}{l}\text { Integration } \\
\text { depth (m) }\end{array}$ & $\begin{array}{l}\text { Salp biomass } \\
\left(\mathrm{mg} C \mathrm{~m}^{-2}\right)\end{array}$ & $\begin{array}{l}\% \text { of water } \\
\text { cleared }\left(\mathrm{d}^{-1}\right)\end{array}$ & $\begin{array}{c}N \text { excretion } \\
(\mu \mathrm{M})\end{array}$ & $\begin{array}{c}\text { Fecal C } \\
\left(\mathrm{mg} \mathrm{m}^{-2} \mathrm{~d}^{-1}\right)\end{array}$ & $\begin{array}{c}\text { Fecal N } \\
\left\{\mathrm{mg} \mathrm{m}^{-2} \mathrm{~d}^{-1}\right\}\end{array}$ \\
\hline 3-5 Aug 1984 & 100 & 411 & 3.8 & 0.003 & 99 & 13 \\
\hline 7-9 Aug 1984 & 100 & 370 & 3.4 & 0.003 & 89 & 11 \\
\hline 10-11 Aug 1988 & 60 & 344 & 4.7 & 0.005 & 83 & 10 \\
\hline 13-14 Aug 1988 & 60 & 85 & 1.2 & 0.001 & 21 & 3 \\
\hline 24-26 Aug 1988 & 60 & 3621 & 49.2 & 0.049 & 875 & 110 \\
\hline
\end{tabular}

not all of the daily fecal production would be exported from the upper waters. Although the salps are diel migrators, the daily excursion was largely within the top $30 \mathrm{~m}$, and there was not a significant acceleration of fecal pellets out of the mixed layer.

\section{DISCUSSION}

When abundant, Cyclosalpa bakeri appears capable of removing a substantial portion of the stock and daily production of autotrophic cells $\geq 5 \mu \mathrm{m}$. Estimates in Table 3 based on pigment ingestion are certainly too high because the salps ingest pigment in both living cells and detritus, while the estimates of chlorophyll stock and primary production are based on live cells only. This can be seen by comparing the fraction of chlorophyll $\geq 5 \mu \mathrm{m}$ ingested (Table 3 ) with the fraction of diatom stocks removed or the fraction of the water filtered on the same dates in 1988 (Table 5). If the ingested pigment were present only in living cells (which were counted to determine chl a stock) these values should be about the same. The nearly 2 -fold difference suggests that about half the pigment ingested by salps was in dead cells or detritus which were not included in the stock estimates.

Data from both 1984 and 1988 (Table 5) indicate that large populations of salps can remove fractions ranging from about 1 to $50 \%$ of the stock and production of phytoplankton daily, and are effective grazers on large cells, like diatoms, which are less subject to microzooplankton grazing. Indeed, as non-selective grazers, the salps are also removing heterotrophic protozoans and probably some metazoan microplankton as well. Independent grazing experiments on several species of ciliates and larger dinoflagellates conducted during the August 1988 SUPER cruise (D. Gifford pers. comm.) yielded mean clearance rates a little lower $\left(0.36 \mathrm{l} \mathrm{mg}^{-1} \mathrm{C} \mathrm{h}^{-1}\right)$ than those we determined from gut pigment (Table 4), perhaps due to confinement effects
(Madin \& Kremer 1995) or particle size differences. Caron et al. (1989) reported that the congeneric Cyclosalpa affinis removed the heterotrophic flagellate Bodo sp. $(2.0$ to $2.5 \mu \mathrm{m})$ at $83 \%$ of the rate for filtration of the phytoflagellate Isochrysis galbana $(5.0 \mu \mathrm{m})$. It is reasonable to assume that stocks of microzooplankton at Station P would be diminished by approximately the same percentages as autotrophs $\geq 5 \mu \mathrm{m}$ (Table 5).

The contribution of salp excretion to ambient nitrogen concentration appears negligible. Ammonium concentrations were generally low in the mixed layer, between 0 and about $0.2 \mu \mathrm{M}$, but with a peak up to almost $0.5 \mu \mathrm{M}$ between 50 and $80 \mathrm{~m}$ in August 1988 (Wheeler 1993). This peak was deeper than the occurrence of Cyclosalpa bakeri, and is unlikely to be related to their excretion. Calculated concentrations due to excretion by salps in the mixed layer (Table 5) are in the nanomolar range, below the limits of analytical detection. Although contributing to the regeneration of nitrogen, salp excretion seems unlikely to have a significant effect on phytoplankton in that depth range

Defecation of carbon and nitrogen are approximately 24 and $3 \%$ of salp carbon biomass, respectively. At the highest abundance recorded on August 24-26, 1988 , the estimated production of fecal carbon is $140 \%$ of the daily primary production for August 25 (Welschmeyer et al. 1993). Estimates from other places of salp fecal flux based on defecation rate and biomass range from 0.01 to $137 \mathrm{mg} \mathrm{C} \mathrm{m} \mathrm{m}^{-2} \mathrm{~d}^{-1}$, while estimates from sediment trap collection of salp fecal pellets are as high as $576 \mathrm{mg} \mathrm{C} \mathrm{m}^{-2} \mathrm{~d}^{-1}$ (Caron et al. 1989, Andersen 1997). Most of our estimates of fecal production by Cyclosalpa bakeri (Table 5) are within this range, but the value of $875 \mathrm{mg} \mathrm{C} \mathrm{m}^{-2} \mathrm{~d}^{-1}$ for August $24-26$ is the highest yet reported for any salp. Although sediment traps were deployed during the SUPER cruises, no particle flux data from SUPER 6 have yet been published. It is therefore not possible to compare salp fecal production with total carbon flux for the same dates at 
Station P; only approximate comparisons can be made between estimated exports due to salp grazing and fluxes measured at various depths. Sediment trap studies at Station P from 1982 through 1986 (Takahashi \& Honjo 1989) revealed that peak fluxes of several diatom species occurred in July through October, with maximum rates approaching 50 frustules $\mathrm{m}^{-2} \mathrm{~d}^{-1}$ at $3800 \mathrm{~m}$. Our estimates of diatom ingestion by $\mathrm{C}$. bakeri in August 1988 are between $5 \times 10^{7}$ and $2 \times 10^{9}$ cells $\mathrm{m}^{-2} \mathrm{~d}^{-1}$. Since the frustules are not digested, this should correspond to an egestion rate, much of which may be exported from the strata where the salps were. Measurements of total organic carbon flux at or near Station $\mathrm{P}$ include values from 1982-84 (Takahashi \& Honjo 1989) that are mostly $<10 \mathrm{mg} \mathrm{C} \mathrm{m}^{-2} \mathrm{~d}^{-1}$ at $3800 \mathrm{~m}$, with a peak of about $35 \mathrm{mg} \mathrm{C} \mathrm{m}^{-2} \mathrm{~d}^{-1}$ in August 1983. Similar values for carbon flux were also measured at 3 depths near Station P in July-August 1975 (Iseki 1981). Regression of these 3 values against depth $\left(\mathrm{r}^{2}=0.99\right)$ permits a rough estimate of the corresponding flux at $60 \mathrm{~m}$, the bottom of the $C$. bakeri distribution, of $11.3 \mathrm{mg} \mathrm{C} \mathrm{m} \mathrm{m}^{-1} \mathrm{~d}^{-1}$. All our estimates of $\mathrm{C}$ export due to salp grazing and defecation (Table 5) are well in excess of this estimate from the same season.

Cyclosalpa bakeri appears not to retain particles smaller than about $5 \mu \mathrm{m}$ (Madin \& Purcell 1992), and is therefore not likely to be a controlling grazer of the small cells which make up the bulk of the primary producers (Booth et al. 1993). Indeed the 'new SUPER synthesis' to explain limitation of phytoplankton growth in the high nutrient subarctic Pacific (Frost 1991, Miller et al. 1991, Miller 1993) absolves copepods of any significant role as controlling grazers, and invokes microzooplankton grazing, rapid regeneration and preferential uptake of ammonium, and replenishment of nitrate via upwelling and diffusion to explain the observed patterns of production and biomass. Control of small $(<10 \mu \mathrm{m})$ cells is attributed to microzooplankton (flagellate and ciliate) grazing, and data from dilution experiments (Welschmeyer et al. 1991, Landry et al. 1993) at Station P support this view.

However, cells larger than $10 \mu \mathrm{m}$ are less likely to be controlled by microzooplankton grazing alone, and diatoms are a persistent and sometimes abundant component of the flora in the subarctic Pacific, particularly in summer (Clemons \& Miller 1984, Booth 1988, Booth et al. 1993). Landry et al. (1993) found that autotrophs and microzooplankton grazers were present in about equal biomass in May 1988, and that the diatom component was mainly small cells. Under these conditions, the micro-grazers would be expected to be able to control phytoplankton growth rates, an expectation that was borne out in shipboard dilution experiments. In August 1988, however, the autotroph biomass exceeded the micro-grazer biomass by a factor of 2 or 3 in situ, and more than half the diatom biomass was made up by large cells (Landry et al. 1993). In shipboard dilution experiments run in August 1988 diatoms grew at rates that would produce blooms in the field.

Two explanations have been advanced to explain how population growth of these larger cells is controlled. Welschmeyer et al. (1991) suggested that diatoms grew rapidly in dilution experiments because they were relieved of the grazing pressure of larger zooplankton (copepods or salps) which keeps them in check in nature. Restriction of growth due to iron deficiency has also been suggested (Miller et al. 1991, Landry et al. 1993, Miller 1993), following the general theory of iron limitation advanced by Martin \& Fitzwater (1988) for high nutrient, low chlorophyll areas of the ocean. Certainly, both mechanisms may be operating, with iron limitation slowing the growth rate of larger cells sufficiently that zooplankton grazing can keep pace (Frost \& Franzen 1992). Preliminary iron enrichment experiments conducted during SUPER cruises gave results in support of Martin's hypothesis (Miller 1993).

Feeding rate determinations for copepods present at Station $\mathrm{P}$ in the spring (Neocalanus plumchrus and $\mathrm{N}$. flemingeri) showed that they consumed 2.6 to $3.9 \%$ of the chlorophyll stock and 6.3 to $15.4 \%$ of daily production, insufficient to control growth of the total phytoplankton population (Dagg 1993a). Some earlier feeding experiments showed that fairly high densities of $N$. plumchrus in containers could control growth of diatoms, relative to controls (Landry \& LehnerFournier 1988), but this is not likely to occur in late summer when species of Neocalanus stop feeding in the mixed layer and enter a diapause period at depth prior to reproduction (Miller \& Clemons 1988). Neither feeding rates nor biomass data have been published for other species of copepods in August 1984 or 1988 at Station P, so it is difficult to estimate the extent to which copepod grazing might regulate large phytoplankton at those times. Studies planned for SUPER on the ability of copepods to graze on large cells in summer were never completed (Miller 1993), so the role of copepod feeding in controlling diatom populations at Station P remains unknown.

Cyclosalpa bakeriappears to be present in the mixed layer at Station P only in late summer. This species is thought to be widely distributed in the Pacific, Atlantic and Indian oceans (van Soest 1974), but there are very few data on its abundance or seasonal occurrence. It was not found at Station P on SUPER cruises in the spring; at a more northerly station (' $\mathrm{R}^{\prime} ; 53^{\circ} \mathrm{N}, 145^{\circ} \mathrm{W}$ ) some salps were collected in August 1984, but none were seen or collected in 1987 or 1988. Although we have evidence of the presence of $C$. bakeri at Station $P$ 
from 3 years, the quantitative collections are only from 10 days in 2 years (Table 2), and it is difficult to estimate a 'typical' impact on the community throughout the summer season. Little is known about the population dynamics of any salp species, and we can only speculate on how abundance and effects of $C$. bakeri might fluctuate at Station P. Rates of individual growth and reproduction (Madin \& Purcell 1992) indicate a minimum generation time of $14 \mathrm{~d}$, during which each solitary generation salp produces an average of 170 aggregate generation offspring, each of which produces 1 new solitary. The resulting gross increase in numbers, assuming a random age distribution of solitary salps and no mortality, would be approximately $1200 \% \mathrm{~d}^{-1}$, and even with $85 \%$ mortality of the aggregate offspring, the population could double daily. Although populations as dense as we found on August 24-26, 1988 might not be sustained, salp abundance could fluctuate between the low and high densities we recorded during the summer season. Based on the range of values in Tables $3 \& 5$, we estimate that an average grazing impact during August and September might be daily removal of 5 to $10 \%$ of the standing stock and production of cells $\geq 5.0 \mu \mathrm{m}$, and that defecation would return about $100 \mathrm{mg} \mathrm{C} \mathrm{m}^{-2} \mathrm{~d}^{-1}$ to the water column.

The reproductive rate of Cyclosalpa bakeri is close to maximum doubling rates of 1.5 to $2.0 \mathrm{~d}^{-1}$ for autotrophic cells at Station P in May 1984 and June and September 1987 (Booth et al. 1993). We do not know for certain whether population growth of this magnitude was taking place during the time we sampled at Station $\mathrm{P}$ because we did not repeatedly sample the same water mass. However, it seems quite possible that population growth of $C$. bakeri occurs rapidly in the mid to late summer in response to growth of larger phytoplankton cells late in the season (Clemons \& Miller 1984) and that the grazing of the salps, alone or in combination with the effects of other grazers or of iron limitation, prevents the accumulation of phytoplankton biomass which is predicted from growth experiments. The development of salp populations in areas where the phytoplankton is dominated by diatoms has been noted in other locations (Fortier et al. 1994, Zeldis et al. 1995).

The salps are not the 'major grazers' in the original sense applied to the subarctic Pacific. They do not filter the small cells that dominate the production and biomass at Station $P$, and they are not present during the spring and early summer when grazing control is operative. But the composition of the plankton community appears to change in late summer, with the departure of Neocalanus, increase in the biomass of large cells, reversal of the autotroph/heterotroph ratio seen in the spring, and appearance of Cyclosalpa bakeri. The salps probably require the presence of the diatoms, and may be at least partly responsible for maintaining the constant diatom biomass in August and September

Acknowledgements. We thank the many participants in SUPER II, IV and VI who helped with collection of salps and shipboard experimental work, and the officers and crew of the RV 'Thomas G. Thompson' (the old one) for helping to make the cruises so productive. $D$. Gifford kindly provided unpublished results from grazing studies on microzooplankton. This research was supported by grants from the NSF Biological Program to L.P.M. (OCE-86-00776), J.E.P. (OCE-86-14201) and C.B.M. (OCE-9012295). This is contribution number 9505 from the Woods Hole Oceanographic Institution and number 2853 from the University of Maryland Center for Environmental Studies.

\section{LITERATURE CITED}

Alldredge AL, Madin LP (1982) Pelagic tunicates: unique herbivores in the marine plankton. BioScience 32:655-663

Andersen $V$ (1997) Salp and pyrosomid blooms and their importance in biogeochemical cycles. In: Bone Q (ed) Biology of pelagic tunicates. Oxford University Press, Oxford, p $79-91$

Andersen V, Nival P (1986) A model of the population dynamics of salps in coastal waters of the Ligurian Sea. J Plankton Res 8:1091-1110

Beklemishev KV (1957) The spatial relationships of marine zoo- and phytoplankton. Trudy Inst Okeanol Akad Nauk SSSR 20:253-378

Booth BC (1988) Size classes and major taxonomic groups of phytoplankton at two locations in the subarctic Pacific Ocean in May and August 1984. Mar Biol 97:275-286

Booth BC, Lewin J, Norris RE (1982) Nanoplankton species predominant in the subarctic Pacific in May and June, 1978. Deep Sea Res 29:185-200

Booth BC, Lewin J, Postel JR (1993) Temporal variation in the structure of autotrophic and heterotrophic communities in the subarctic Pacific. Prog Oceanogr 32:57-99

Caron DA, Madin LP, Cole JJ (1989) Composition and degradation of salp fecal pellets: implications for vertical flux in oceanic environments. J Mar Res 47:829-850

Clemons MJ, Miller CB (1984) Blooms of large diatoms in the oceanic subarctic Pacific. Deep Sea Res 31:85-95

Dagg M (1993a) Grazing by the copepod community does not control phytoplankton production in the subarctic Pacific Ocean. Prog Oceanogr 32:163-183

Dagg M (1993b) Sinking particles as possible source of nutrition for the large calanoid copepod Neocalanus cnstatus in the subarctic Pacific Ocean. Deep Sea Res 40:1431-1445

Dagg MJ, Walser WE (1987) Ingestion, gut passage, and egestion by the copepod Neocalanus plumchrus in the laboratory and in the subarctic Pacific Ocean. Limnol Oceanogr 32:178-188

Fortier L, LeFevre J, Legendre L (1994) Export of biogenic carbon to fish and to the deep ocean: the role of large planktonic microphages. J Plankton Res 16:809-839

Frost BW (1991) The role of grazing in nutrient-rich areas of the open sea. Limnol Oceanogr 36:1616-1630

Frost BW, Franzen NC (1992) Grazing and iron limitation in the control of phytoplankton stock and nutrient concentration: a chemostat analogue of the Pacific equatorial upwelling zone. Mar Ecol Prog Ser 83:291-303 
Heinrich AK (1962) The life history of plankton animals and seasonal cycles of plankton communities in the oceans. $\mathrm{J}$ Cons Int Explor Mer 27:15-24

Heron AC (1972) Population ecology of a colonizing species: the pelagic tunicate Thalia democratica II. Population growth rate. Oecologia 10:294-312

Iseki K (1981) Vertical transport of particulate organic matter in the deep Bering Sea and Gulf of Alaska. J Oceanogr Soc Jpn 37:101-110

Landry MR, Lehner-Fournier JM (1988) Grazing rates and behaviors of Neocalanus plumchrus: implications for phytoplankton control in the subarctic Pacific. Hydrobiologia 167/168:9-19

Landry MR, Monger BC, Selph KE (1993) Time-dependency of microzooplankton grazing and phytoplankton growth in the subarctic Pacific. Prog Oceanogr 32:205-222

Le Borgne R (1983) Note sur les proliferations de Thaliaces dans le Golfe de Guinee. Oceanogr Trop 18:49-54

Madin LP (1982) The production, composition and sedimentation of salp fecal pellets in oceanic waters. Mar Biol 67:39-45

Madin LP, Deibel D (1997) Feeding and energetics of Thaliaceans. In: Bone $Q$ (ed) Biology of pelagic tunicates. Oxford University Press, Oxford, p 43-64

Madin LP, Kremer P (1995) Determination of the filter-feeding rates of salps (Tunicata, Thaliacea). ICES J Mar Sci 52: $583-595$

Madin LP, Purcell JE (1992) Feeding, metabolism and growth of Cyclosalpa bakeri in the subarctic Pacific. Limnol Oceanogr 37:1236-1251

Martin JH, Fitzwater S (1988) Iron deficiency limits phytoplankton growth in the northeast Pacific subarctic. Nature 331:341-343

Miller CB (1993) Pelagic production processes in the Subarctic Pacific. Prog Oceanogr 32:1-15

Miller CB, Clemons MJ (1988) Revised life history analysis for

Editorial responsibility: Michael Landry (Contributing

Editor), Honolulu, Hawaii, USA large grazing copepods in the subarctic Pacific Ocean Prog Oceanogr 20:292-313

Miller CB, Frost BW, Wheeler PA, Landry MR, Welschmeyer NA, Powell TM (1991) Ecological dynamics in the subarctic Pacific, a possibly iron-limited system. Limnol Oceanogr 36:1600-1615

Purcell JE, Madin LP (1991) Diel patterns of migration, feeding, and spawning by salps in the subarctic Pacific. Mar Ecol Prog Ser 73:211-217

Takahashi K, Honjo S (1989) Siliceous phytoplankton flux interannual variability and response to hydrographic changes in the Northeastern. Pacific. Geophys Monogr 55:151-160

van Soest RWM (1974) Taxonomy of the subfamily Cyclosalpinae Yount, 1954 (Tunicata, Thaliacea), with descriptions of two new species. Beaufortia 22:17-55

Welschmeyer NA, Goericke R, Strom S, Peterson W (1991) Phytoplankton growth and herbivory in the subarctic Pacific: a chemotaxonomic analysis. Limnol Oceanogr 36: $1631-1649$

Welschmeyer NA, Strom S, Goericke R, DiTullio C, Belvin M, Petersen W (1993) Primary production in the subarctic Pacific Ocean: project SUPER. Prog Oceanogr 32:101-135

Wheeler PA (1993) New production in the subarctic Pacific Ocean: net changes in nitrate concentrations, rates of nitrate assimilation and accumulation of particulate nitrogen. Prog Oceanogr 32:137-161

Wiebe PH, Madin LP, Haury LR, Harbison GR, Philbin LM (1979) Diel vertical migration by Salpa aspera: potential for large-scale particulate organic matter transport to the deep sea. Mar Biol 53:249-255

Zeldis JR, Davis CS, James MR, Ballara SL, Booth WE, Chang FH (1995) Salp grazing: effects on phytoplankton abundance, vertical distribution and taxonomic composition in a coastal habitat. Mar Ecol Prog Ser 126:267-283

Submitted: February 7, 1997; Accepted: July 5, 1997

Proofs received from author(s): September 23, 1997 